Journal of Environmental Science and Sustainable Development

$12-31-2019$

\title{
ENVIRONMENTAL ANALYSIS OF TOFU PRODUCTION IN THE CONTEXT OF CLEANER PRODUCTION: CASE STUDY OF TOFU HOUSEHOLD INDUSTRIES IN SALATIGA, INDONESIA
}

\author{
Gefa Satria Fajar Nugroho \\ Universitas Kristen Satya Wacana, Jl. Diponegoro 52-60 Salatiga, Central Java, Indonesia \\ Ravika Sulistyaningrum \\ Universitas Kristen Satya Wacana, Jl. Diponegoro 52-60 Salatiga, Central Java, Indonesia \\ Reindra Prastiwa Melania \\ Universitas Kristen Satya Wacana, Jl. Diponegoro 52-60 Salatiga, Central Java, Indonesia \\ Widhi Handayani \\ Universitas Kristen Satya Wacana, Jl. Diponegoro 52-60 Salatiga, Central Java, Indonesia, \\ widhyandayani@gmail.com
}

Follow this and additional works at: https://scholarhub.ui.ac.id/jessd

Part of the Social and Behavioral Sciences Commons

\begin{abstract}
Recommended Citation
Nugroho, Gefa Satria Fajar; Sulistyaningrum, Ravika; Melania, Reindra Prastiwa; and Handayani, Widhi (2019). ENVIRONMENTAL ANALYSIS OF TOFU PRODUCTION IN THE CONTEXT OF CLEANER PRODUCTION: CASE STUDY OF TOFU HOUSEHOLD INDUSTRIES IN SALATIGA, INDONESIA. Journal of Environmental Science and Sustainable Development, 2(2), 127-138.

Available at: https://doi.org/10.7454/jessd.v2i2.1021
\end{abstract}

This Case-Based Article is brought to you for free and open access by the School of Environmental Science at UI Scholars Hub. It has been accepted for inclusion in Journal of Environmental Science and Sustainable Development by an authorized editor of UI Scholars Hub. 


\title{
ENVIRONMENTAL ANALYSIS OF TOFU PRODUCTION IN THE CONTEXT OF CLEANER PRODUCTION: CASE STUDY OF TOFU HOUSEHOLD INDUSTRIES IN SALATIGA, INDONESIA
}

\author{
Gefa Satria Fajar Nugroho, Ravika Sulistyaningrum, Reindra Prastiwa Melania, Widhi \\ Handayani*
}

Universitas Kristen Satya Wacana, Jl. Diponegoro 52-60 Salatiga, Central Java, Indonesia

*Corresponding author: e-mail: widhyandayani@gmail.com

(Received: 7 November 2019; Accepted: 13 December 2019; Published: 31 December 2019)

\begin{abstract}
Tofu is a soy-based food that is frequently consumed by Indonesian as a protein source. It is usually produced by household industries using traditional technology, which currently experiencing environmental problems with respect to the inefficiency of resource usage and inadequate waste disposal. Therefore, cleaner production strategy is potential to be implemented by previously mapping the current problems faced by the industries. This study aims to present an environmental analysis on tofu production in Salatiga in the context of cleaner production. In addition to provides information about the current production process and explains waste management performed by the industries, this study describes how the people in Kalitaman-Salatiga consider environmental issue around the tofu production. This study was conducted by a qualitative approach using interview, observation, and documentation. Laboratory analysis was conducted to provide supporting data. The results showed that only a small proportion of the tofu production process in Kalitaman meets the indicators for cleaner production in term of using raw materials efficiently and reusing solid wastes. Wastes in the form of smoke and wastewater are still disposed without prior treatment. The BOD5, COD, and TSS contents of tofu wastewater exceed the quality standard set by the Indonesian government. Although the respondents understand the negative impact of pollution to ecosystem, they are not yet concerned because it does not show a direct detrimental impact on their community. Therefore, raising environmental awareness is required in order to protect the ecosystem and to prevent environmental deterioration.
\end{abstract}

Keywords: cleaner production; environmental awareness; household industry; tofu

\section{Introduction}

An adequate and continuous food supply is required to fulfill the food security needs of the Indonesian population. In this respect, tofu and tempeh are legume-based foods that provide the protein requirements of people, and they are thus eaten frequently. Tofu is an excellent protein source (100 g contains $30.7 \mathrm{~g}$ of protein in addition to $12.69 \mathrm{~g}$ of fat and $4.18 \mathrm{~g}$ of carbohydrate) (Alamu, Therese, Mdziniso, \& Bussie, 2017). Furthermore, isoflavones, aglycones, and proteins contained in tofu have antioxidant properties as a protection from lipid 
oxidation (Dey, Prasad, Kaur, Singh, \& Luwang, 2017). Komalasari et al. (2017) explained that the amount of tofu and tempeh consumed weekly per capita had grown by $3.80 \%$ and $2.06 \%$, respectively in 2017, compared with 2013. Furthermore, the annual average consumption of tofu and tempeh per capita had grown by $3.98 \%$ and $2.13 \%$, respectively, within the same time frame. This indicates that the consumption of both tofu and tempeh has increased, but tofu is the preferred food.

In Indonesia, tofu and tempeh are usually produced by home industries using traditional technology. Ridha (2015) reported that these industries produce approximately 57 million EUR per year and generate income for about 85,000 businesses and 285,000 workers. However, these soybean processing industries are considered to be inefficient; not only has there been a reduction in productivity, but the processes employed are considered to be environmentally damaging (Ridha, 2015). According to Faisal, Gani, Mulana, \& Daimon (2016), tofu wastewater contains high levels of BOD and COD in the range of $6,000-8,000 \mathrm{mg} / \mathrm{L}$ and 7,500-14,000 mg/L, respectively. The level of organic substances is still high at above 500 $\mathrm{mg} / \mathrm{L}$, even after the wastewater has been treated (Faisal et al., 2016). The Government of Salatiga (2012) is aware that these tofu industries are polluting the environment, although the data have not yet been provided, and the government has tried to support some of the tofu industries by providing biogas installations in Tingkir and Banyuputih, and constructed Wastewater Treatment Plant in Banyuputih.

In this context, the concept of cleaner production becomes potential to apply. According to ILO (2013), cleaner production is a strategy to reduce environmental pollution and simultaneously reducing the use of resources. It focuses mainly on the effort to prevent unnecessary use of resources and making overall pollution control as the last option. The application of cleaner production together with good management practices is expected to increase additional value and increase the productivity of the enterprise itself as well as the welfare of the workers.

Implementation of cleaner production usually involves three steps, i.e, (1) mapping the problem faced by the industry; (2) implementing the cleaner production technology; and (3) evaluating the implementation. Furthermore, the cleaner production concept involves SMEs making an effort to increase production based on several indicators, which are as follows: (1) that the disposal of waste is minimized and prevented where possible; (2) that waste is recovered and reused; and (3) that cleaner and more efficient energy sources are employed (ILO, 2013). Based on these indicators, this research questioning "Does the tofu production by traditional technology meet the cleaner production indicators?" Therefore, this study aims to present an environmental analysis on tofu production in Salatiga in the context of cleaner production. In case the tofu industries are commonly related to contributors of environmental pollution, particularly because of its wastewater, the study includes an explanation of how current tofu waste processing can be seen as an added value for these industries.

While studies on environmental aspect of tofu production mainly focused on the wastewater and how to solve the problem, studies which explores the environmental behavior of the workers or population who deal with the environmental aspect is very limited. Meanwhile, understanding the pro-environmental behavior in population is fundamental to address challenges in environmental protection and restoration (Bronfman, Cisternas, López-Vázquez, Maza, \& Oyanedel, 2015). Hence, this study also explores the community's understanding of 
the corresponding impact of the environmental destruction. In addition to providing information about the current production practices performed by tofu household industries in Salatiga in the context of cleaner production and explaining waste management practices performed by the household industries, this study describes how the citizens of Kalitaman consider this issue, and to map subsequent steps that can be taken to overcome these problems. However, as this research is a qualitative study, the conclusions made cannot be generalized to other populations.

\section{Methods}

This study was conducted from February to August 2019 in Kalitaman, Sidorejo subdistrict, Salatiga. The location was selected based on data obtained from Dinas Perindustrian Kota Salatiga, which shows that 15 of the town's 40 tofu industries are located in Kalitaman. This study employed a qualitative approach based on consideration that industrial environmental problems mostly related to human activities, which is linked to their behavior as well. As written by Guba \& Lincoln (1994), human behavior cannot be understood without references to the meanings and purposes of human activities, and this is why qualitative data could be asserted in order to provide rich insight to human behavior.

In qualitative study, the researcher is a key instrument who collects the data through documentation, observing behavior of the respondents or participants, and interview (Creswell, 2014). Using snowballing and accidental techniques, nine respondents were selected for interview; two respondents were owners of tofu industries, two were workers in the industries, three were residents of Kalitaman, and two were residents of Domas village. We selected two household tofu industries in Kalitaman based on the consideration that those industries are the largest among others. It is assumed that the larger industries will use more raw materials, resources, and possibly generates wastes in a larger amount or volume than other smaller industries. The latter respondents were selected to obtain information about the impact of tofu wastewater, which usually flows from Kalitaman to Domas.

The data for this research was collected via in-depth interviews, observations, and research documentation. In depth interview with the respondents was conducted for twice to three times and the interview took a period of 20-30 minutes for each respondent per interview. In addition to the interview, observation was also conducted to enable a description of the waste treatment and to determine the added value that can be obtained from tofu waste. Picture documentations were taken to record the process of tofu production, the waste management and the impact of tofu wastewater to the environment.

In order to support the qualitative study, sample of tofu wastewater was collected and analyzed for $\mathrm{pH}$ and contents of total suspended solids (TSS), BOD5, COD, and $\mathrm{N}-\mathrm{NH}_{3}$. The pH was measured using a Hanna $\mathrm{HI}$ 9811-5 kit; TSS and $\mathrm{NH}_{3}$ were determined using a DR/2000 HACH Direct Reading Spectrophotometer; and BOD5 and COD were analyzed using the iodometric and open reflux method, based on Kruis (1995). However, it should be noted that the sample collection was conducted only once because it is only intended as supporting data, instead as a main data. All data in the form of interview transcripts were analyzed using a descriptive qualitative method and are presented in a narrative form. The results of the laboratory analyses were compared to the permissible limit for wastewater of soybean (tofu) processing industries regulated by The Ministry of Environment and Forestry of Republic of 
Indonesia through regulation no. 5/2014 (Kementerian Lingkungan Hidup, 2014) and to other relevant studies. Finally, in order to answer the research question proposed in previous section, we compared all the results to indicators of cleaner production set by ILO (2013).

\section{Results and Discussion}

\subsection{Tofu Production Process}

As previously explained, tofu is produced by industries using traditional technology (Faisal et al., 2016). While tempeh is fermented using the mold of Rhizopus sp. (Surono, 2016), tofu is produced by coagulation. Sortation is the first step in the production process, and it is conducted to guarantee the quality of the tofu (Kaswinarni, 2007). In this study, the industries use local soybeans to produce the tofu, and after sortation, the soybeans are soaked for approximately three to four hours. The beans are then ground, which produces a yellowish-white soybean milk (Figure 1b).

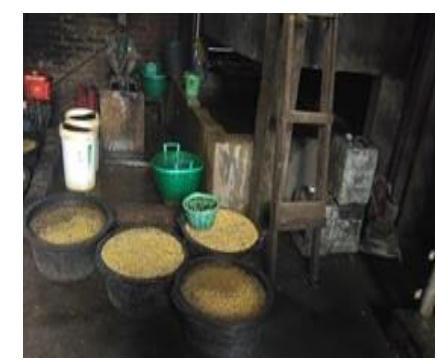

(a)

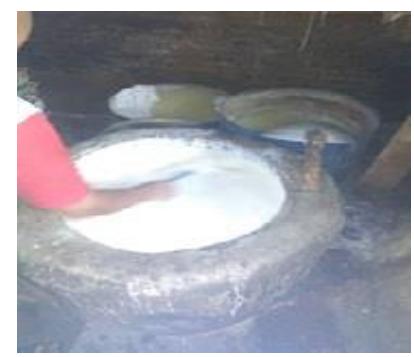

(c)

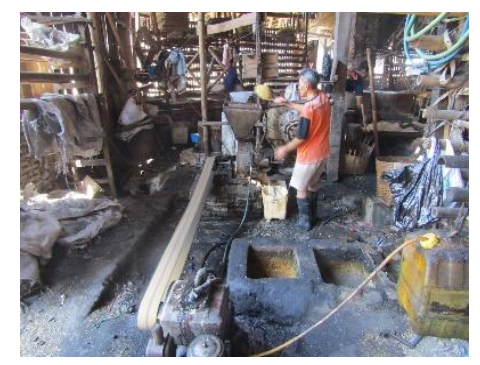

(b)

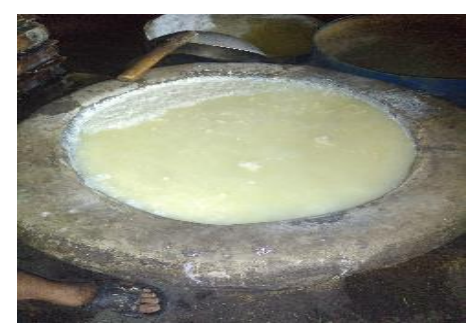

(d)

Figure 1. (a) soaking; (b) grinding; (c) boiling; (d) coagulation of soybean milk

The milk is then boiled for about 30 minutes until it becomes a soybean porridge-like substance, and it is then filtered using a white cloth. The filtrate is coagulated by adding whey to produce white tofu curd, and the residue is usually sold at a very cheap rate and processed to make mentho, gembus, or to feed cattle. Therefore, the solid waste is not useless, and it can be processed and reused as other products, as outlined in Widaningrum (2015) and Faisal et al. (2016). 


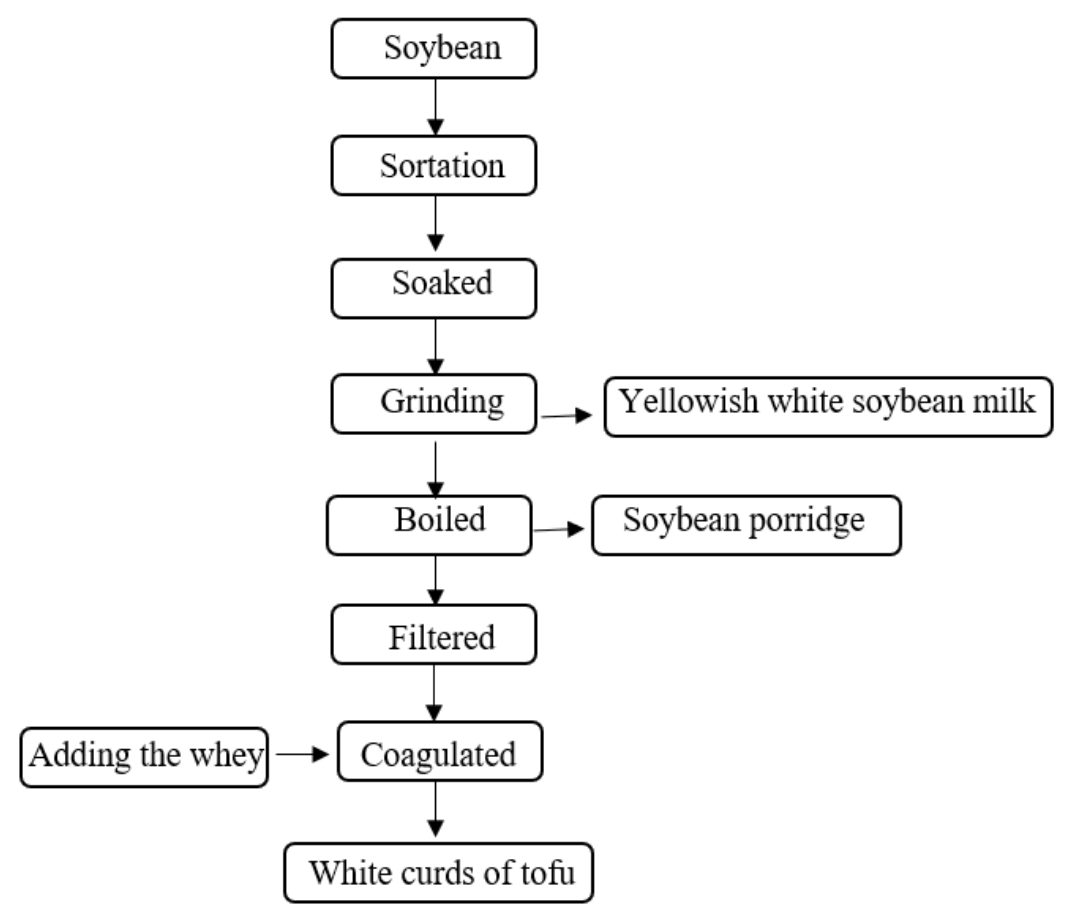

Figure 2. Tofu production

The raw materials for tofu production are soybeans, water, rice husk for fuel, and cooking oil for frying the tofu. Each cooking process produces eight packages of tofu (measuring $40 \mathrm{~cm} \times 40 \mathrm{~cm} \times 3.5 \mathrm{~cm}$ each), with a volume equal to $5,600 \mathrm{~cm}^{3}$. The process is usually conducted 25 times daily, on average; therefore, 200 packages can be produced in one day.

Table 1. Estimation of raw materials and tofu produced during production

\begin{tabular}{|c|c|c|c|}
\hline Production factors & $\begin{array}{l}\text { Quantity } \\
\text { (unit/day) }\end{array}$ & $\begin{array}{c}\text { Price per } \\
\text { unit } \\
\text { (IDR/day) }\end{array}$ & $\begin{array}{c}\text { Total cost/ } \\
\text { income } \\
\text { (IDR/day) }\end{array}$ \\
\hline \multicolumn{4}{|l|}{ 1. Raw materials } \\
\hline a. Soybean & $375 \mathrm{~kg}$ & 8,000 & $3,000,000$ \\
\hline b. Water & $100 \mathrm{~L}$ & --- & --- \\
\hline c. Rice husk & 1 package & 475,000 & 475,000 \\
\hline d. Cooking oil & $0.54 \mathrm{~kg}$ & 9,000 & 4,860 \\
\hline \multicolumn{4}{|l|}{ e. Worker(s): } \\
\hline Grinding & 1 person & 75,000 & 75,000 \\
\hline Cooking & 4 persons & 75,000 & 300,000 \\
\hline Frying & 3 persons & 58,300 & 175,000 \\
\hline \multicolumn{3}{|c|}{$\begin{array}{r}\text { Total production cost } \\
\end{array}$} & $4,025,000$ \\
\hline \multicolumn{4}{|c|}{\begin{tabular}{|l|l} 
2. Income from selling & \\
\end{tabular}} \\
\hline a. White tofu & 9600 slices & 500 & $4,800,000$ \\
\hline b. Fried tofu & 6400 slices & 200 & $1,280,000$ \\
\hline \multicolumn{3}{|c|}{ Total income from tofu production } & $6,080,000$ \\
\hline \multicolumn{3}{|c|}{ Profit/day } & $2,055,000$ \\
\hline
\end{tabular}


Based on our measurements, the size of a slice of tofu is $5 \mathrm{~cm} \times 4 \mathrm{~cm} \times 3.5 \mathrm{~cm}$ (or equal to 70 $\mathrm{cm}^{3}$ ). Therefore, a package of tofu measuring $5600 \mathrm{~cm}^{3}$ is equal to 80 slices, with an average weight per slice of $0.0779 \mathrm{~kg} / \mathrm{slice}$. This means that 200 packs are equal to 16,000 slices of tofu, or $1,246 \mathrm{~kg}$ of tofu; $60 \%$ of this is white tofu and $40 \%$ is fried tofu. Assuming that all the tofu is sold in one day, the income of an entrepreneur per day can be estimated (and is shown in Table 1).

\subsection{Analysis of Cleaner Production in Tofu Household Industries}

The results of this study is compared to indicators of cleaner production as suggested by ILO (2013), which focus on prevention of waste generation, reuse and recycle process, and the use of cleaner energy (Table 2). Regarding to the first indicator, we found that the raw materials are used efficiently. Our study found that $375 \mathrm{~kg}$ of soybean per day results in the production of $1,246 \mathrm{~kg}$ of tofu, and the soybean/tofu ratio is 0.300. The report of Haidir \& Sudrajat (2014) showed that a tofu industry in Bandung produced $900 \mathrm{~kg}$ of tofu per day from $500 \mathrm{~kg}$ of soybeans, with a soybean/tofu ratio of 0.555 . This indicates that tofu production in Kalitaman is more efficient than that in Bandung, as more tofu is produced from fewer soybeans. However, the use of water is of concern, mainly because it can be accessed at no cost (Table 1), which could lead to excessive water use behavior.

Table 2. Cleaner production analysis of tofu home industries

\begin{tabular}{|c|c|c|c|}
\hline No. & $\begin{array}{l}\text { Indicators of cleaner } \\
\text { production (ILO, 2013) }\end{array}$ & Activities & Analysis \\
\hline 1. & $\begin{array}{l}\text { Prevention and } \\
\text { minimization of waste } \\
\text { (prevent waste generation } \\
\text { and guarantee efficient use } \\
\text { of resources). }\end{array}$ & $\begin{array}{l}\text { Raw materials are used } \\
\text { efficiently; however, the } \\
\text { use of water requires } \\
\text { study, as there is currently } \\
\text { no price for water } \\
\text { available. The production } \\
\text { still generates waste. }\end{array}$ & $\begin{array}{l}\text { The activities meet the } \\
\text { indicators of cleaner } \\
\text { production in term of using } \\
\text { raw materials efficiently, } \\
\text { however the process still } \\
\text { generates waste. }\end{array}$ \\
\hline 2. & $\begin{array}{l}\text { Reuse and recycle } \\
\text { (recovery of materials and } \\
\text { waste for productive use). }\end{array}$ & $\begin{array}{l}\text { Solid waste is processed } \\
\text { for use as food, cattle feed, } \\
\text { and fertilizer; smoke and } \\
\text { wastewater are released } \\
\text { without being treated. }\end{array}$ & $\begin{array}{l}\text { The reuse and recovery of } \\
\text { solid waste is conducted. } \\
\text { However, smoke and } \\
\text { wastewater should be } \\
\text { treated prior to release. }\end{array}$ \\
\hline 3. & $\begin{array}{l}\text { Cleaner and efficient } \\
\text { energy (maximize energy } \\
\text { input and minimize } \\
\text { pollution). }\end{array}$ & $\begin{array}{l}\text { Diesel fuel and rice husks } \\
\text { are the energy source used } \\
\text { in production. These } \\
\text { processes still generate } \\
\text { smoke due to the } \\
\text { combustion of husks. }\end{array}$ & $\begin{array}{l}\text { Although an appropriate } \\
\text { machine is used for } \\
\text { processing, the process } \\
\text { generates smoke. A cleaner } \\
\text { production technology is } \\
\text { required to improve the } \\
\text { process. }\end{array}$ \\
\hline
\end{tabular}


This study also found that tofu production generates waste in solid, liquid, and gaseous phases. The wastes generated were soybean milk residue, tofu wastewater, and smoke from combustion, respectively. The household industries are usually selling the waste or using them as food for cattle as previously explained. Nevertheless, some efforts are required to treat the smoke and wastewater prior to release as well as finding a cleaner technology which could bring cleaner energy in order to reduce emission. Therefore, in general, implementation of cleaner production in tofu production by household industries is a challenge that needs to be addressed.

\subsection{Characteristics of Kalitaman's Tofu Wastewater}

This study also examines the characteristics of tofu wastewater, because the wastewater is commonly discharged into the river or tributaries, which lead to river pollution. Table 3 presents the tofu wastewater characteristics of Kalitaman's tofu industry in comparison to other tofu wastewater characteristics.

Table 3. Characteristics of tofu wastewater

\begin{tabular}{|l|c|c|c|c|c|}
\hline \multirow{2}{*}{ Parameters } & \multicolumn{4}{|c|}{$\begin{array}{c}\text { Concentrations of pollutants in tofu wastewater from Kalitaman compared to } \\
\text { other studies and the Ministry of Environment and Forestry Regulations }\end{array}$} \\
\cline { 2 - 6 } & $\begin{array}{c}\text { Kalitaman- } \\
\text { Salatiga } \\
\text { (this study) }\end{array}$ & $\begin{array}{c}\text { Banda Aceh } \\
\text { (Faisal et al., } \\
2014)\end{array}$ & $\begin{array}{c}\text { South Jakarta } \\
\text { (Oktariany \& } \\
\text { Kartohardjono, } \\
2018)\end{array}$ & $\begin{array}{c}\text { Other study } \\
\text { (Seroja et } \\
\text { al., 2018) }\end{array}$ & $\begin{array}{c}\text { Quality } \\
\text { standard } \\
\text { (Kementerian } \\
\text { Lingkungan } \\
\text { Hidup, 2014) }\end{array}$ \\
\hline $\mathrm{pH}$ & 4.20 & $4.82-5.50$ & 3.80 & 3.90 & $6-9$ \\
\hline $\mathrm{TSS}(\mathrm{mg} / \mathrm{L})$ & 2,075 & $\begin{array}{c}1,050-3,130 \\
\text { (MLSS) }\end{array}$ & $381-414$ & 552 & 200 \\
\hline $\mathrm{BOD} 5(\mathrm{mg} / \mathrm{L})$ & 766 & $3,500-4,500$ & 2,900 & 580 & 150 \\
\hline $\mathrm{COD}(\mathrm{mg} / \mathrm{L})$ & 6,600 & $5,000-8,500$ & $5,981-6,525$ & 5,759 & 300 \\
\hline $\mathrm{N}-\mathrm{NH} \mathrm{H}_{3}(\mathrm{mg} / \mathrm{L})$ & 24.00 & $\begin{array}{c}33.00- \\
129.00\end{array}$ & --- & -- & -- \\
\hline
\end{tabular}

It is shown in Table 2 that tofu wastewater of Kalitaman's tofu industry are similar to those of Banda Aceh (Faisal et al., 2014), but the $\mathrm{pH}$ and BOD5 and $\mathrm{NH}_{3}-\mathrm{N}$ contents are lower than those of Banda Aceh. The differences in $\mathrm{pH}$ may be related to the usage of vinegar for coagulation in Kalitaman, and this acidic characteristic may inhibit bacterial degradation of the tofu wastewater, as expected by the lower BOD5 value.

In comparison to the study of Seroja et al. (2018), it is indicated that the pH of Kalitaman's tofu wastewater was a bit higher, which could lead to the higher BOD5 concentration. However, the finding of Oktariany \& Kartohardjono (2018) does not support this reason as the low $\mathrm{pH}$ of South Jakarta's tofu wastewater was not followed by the low BOD. Instead, its BOD value was much higher than our finding and the finding of Seroja et al. (2018). However, high concentration in BOD strongly indicates the need of oxygen in biological oxidation of organic matter in the wastewater. In regard to COD, all data indicates the high concentration of COD and the concentrations were in the range of $5,000-8,500 \mathrm{mg} / \mathrm{L}$ as reported by Faisal et al. 
(2014). Nevertheless, these data indicate that the characteristics of tofu wastewater exceeds the quality standard for tofu wastewater regulated by the Kementerian Lingkungan Hidup (2014).

\subsection{Tofu Waste in the Perception of Kalitaman and Domas People}

Based on the results of interviews, the respondents understand that pollution degrades the natural environment. They recognized that tofu wastewater causes water pollution as it is usually discharged into the tributary behind the factories and it flows into Domas village. Nevertheless, the interviews showed that people did not consider the wastewater to be a disadvantage, as the materials within it are used to fertilize paddy fields. According to Dianursanti et al. (2014), tofu wastewater still contains protein, lipids, carbohydrate, and fats. Therefore, the discharge of tofu wastewater into surface water increases the total nitrogen of the water. Moreover, a recent study showed that tofu wastewater has a potential to be processed as liquid fertilizer to support the growth of pepper through lorong garden program (Saenab et al., 2018) and it is used to fertilize maize (Hidayani et al., 2015). Furthermore, in their opinion they do not suffer from the water pollution because they do not usually use the water from the polluted tributary. Instead, they get clean and fresh water from a spring namely Kali Wedok for their daily life.

The people also understand that the combustion of husks causes air pollution. However, the smoke resulted from the combustion does not bother the people, because the smoke will be carried by the wind, and hence, they do not suffer from the smoke. This indicates that the main focus of the people is not to the detrimental effect of the pollution to natural ecosystem, but rather to themselves.

This study found that some activities of the industries have put the effort in using the raw materials efficiently and reuse solid wastes. However, other efforts are required to provide cleaner energy innovation and minimizing wastewater, as wastewater and smoke are still released without being treated. Our study found that these industries use diesel to grind the soybeans and rice husks to boil the soybean milk. According to Sahirman \& Ardiansyah (2014), diesel uses $1.46 \mathrm{MJ} / \mathrm{kg}$ tofu and emits $107.13 \mathrm{CO}_{2} \mathrm{e} \mathrm{g} / \mathrm{kg}$ tofu, while firewood uses $9.93 \mathrm{MJ} / \mathrm{kg}$ tofu and emits $1,591.99 \mathrm{CO}_{2} \mathrm{e} \mathrm{g} / \mathrm{kg}$ tofu. The production of smoke also indicates that cleaner energy usage has not been achieved, and this may be related to the lack of available technology. Ridha (2015) showed that soy-based food industries in Indonesia face several problems related to inefficiency, inadequate waste disposal, lack of hygiene, and a low awareness of new technologies. This situation is in line to the idea of Gorobets (2014) who highlighted human behaviour, population increase, and limits to technological efficiency as the cause of current systemic environmental problems.

Alternatives to treat tofu wastes are available, for example by phytoremediation (Seroja et al., 2018) and using coagulant in combination with membrane technology (Oktariany \& Kartohardjono, 2018) to treat the wastewater. Moreover, other alternatives can be made to process the wastewater into useful products such as biogas (Ristianingsih et al., 2018; Syaifudin et al., 2018), and to cultivate Chlorella vulgaris as a source of lipid for biodiesel production (Dianursanti et al., 2014). The potential of tofu solid wastes to produce bioethanol (Febrianti et al., 2017) and soybean oil as a potential source of biodiesel (Buchori et al., 2012) is also reported. The conversion of tofu wastes into useful products does not only give advantage in preventing pollution, but also providing alternative energy and added value to the industries. 
Innovation in technology could be also considered to save resources and energy. The use of LPG to replace wood or husks followed by improving the design of stove for cooking the soybean porridge has been reported to save $72.2 \%$ of energy compared to before replacement (Darmajana et al., 2013). Nevertheless, human lifestyle change is the key to reduce detrimental effect of their behavior to the environment (Gorobets, 2014).

This study also found the understanding of people in Kalitaman and Domas regarding to environmental pollution caused by tofu wastes. They define pollution in relation to its negative environmental impact; however, as the impact is not directly negative for them, they are not concerned about it. Pollution only concerns them when it has a direct detrimental effect on their community. However, when a detrimental effect on the community eventually occurs, the quality of the ecosystem will have been downgraded to such an extent that amelioration will be difficult. This situation indicates anthropocentric perspective which is rooted strongly in the mind of people.

According to Thompson \& Barton (1994), anthropocentrics are utilitarian and they value nature only because of its contribution to their human satisfaction. This paradigm is different from the eco-centrics, who aim to save nature because it has value that is independent of them. As the anthropocentric view in environmental issues is a challenge, therefore, a change to ecocentric behavior is necessary to raise awareness and change human lifestyle. In this case, there are three approaches presented by Gorobets (2014), i.e. (1) educational policies which focused on eco-centric behavior rather than profit motives since childhood; (2) integrated knowledge about environmental problems which is provided by educational programs to raise awareness and personal responsibility for their lifestyle and the impact to the environment; (3) environmental research and restoration projects which involved public participation.

\section{Conclusion}

The tofu production by household industries in Kalitaman did not yet meet the indicators of cleaner production, although they have used raw materials efficiently and reused solid wastes. The production still generates solid waste, smoke, and wastewater. The BOD5, COD, and TSS contents of tofu wastewater are $766 \mathrm{mg} / \mathrm{L}, 2,075 \mathrm{mg} / \mathrm{L}$, and $6,600 \mathrm{mg} / \mathrm{L}$, which exceed the quality standard set by the Government of Indonesia. More efforts are needed to provide cleaner energy and treat the wastewater, as wastewater and smoke are still released without being treated. The respondents in Kalitaman and Domas understand the negative impact of pollution to natural ecosystem. However, they are not yet concerned about its impact because it does not have a direct detrimental impact on their community. Therefore, promoting environmental awareness in the community in Kalitaman is required, particularly with respect to preventing environmental degradation before it is too late.

\section{Author Contributions}

Reindra Prastiwa Melania developed the background, results and discussion, bibliography. Gefa Satria Fajar Nugroho developed the methods, results and discussion, bibliography. Ravika Sulistyaningrum developed the results and discussion, conclusions, bibliography. Widhi Handayani carried out the results and discussion (specifically on the analysis of the characteristics of tofu wastewater and analysis of the effects of anthropocentrism), as well as improving the background. 


\section{References}

Alamu, E. O., Therese, G., Mdziniso, P., \& Bussie, M.-D. (2017). Assessment of nutritional characteristics of products developed using soybean (Glycine max (L.) Merr.) pipeline and improved varieties. Cogent Food \& Agriculture, 3(1), 1-12. https://doi.org/10.1080/23311932.2017.1398042

Bronfman, N. C., Cisternas, P. C., López-Vázquez, E., Maza, C. de la, \& Oyanedel, J. C. (2015). Understanding attitudes and pro-environmental behaviors in Chilean community. Sustainability, 7, 14133-14152. https://doi.org/10.3390/su71014133

Buchori, L., Sasongko, S. B, Anggoro, D. D., Aryanti, N. (2012). Extracting soybean oil from tofu waste as raw material for making biodiesel (Pengambilan minyak kedelai dari ampas tahu sebagai bahan baku pembuatan biodiesel). Jurnal Ilmu Lingkungan, 10(2), 49-53. https://ejournal.undip.ac.id/index.php/ilmulingkungan/article/view/4103/PDF

Creswell, J. W. (2014). Research Design: Qualitataive, Quantitative, and Mixed Approach. Jogyakarta: Pustaka Pelajar.

Darmajana, D. A., Afifah, N., Novrinaldi, Hanifah, U., \& Taufan, A. (2013). Efficiency of Water and Energy Use Based on Cleaner Production in Small Tofu Industry: A Case Study of SME Tofu "Sari Rasa" Subang. Pangan 22(4), 373-384. https://jurnalpangan.com/index.php/pangan/article/view/140/0

Dey, A., Prasad, R., Kaur, S., Singh, J., \& Luwang, M. D. (2017). Tofu: Technological and nutritional potential. Indian Food Industry Magazine, 36(3), 8-24. https://www.researchgate.net/publication/323676422_Tofu_technological_and_nutritional _potential

Dianursanti, Rizkytata, B. T., Gumelar, M. T., \& Abdullah, T. H. (2014). Industrial tofu wastewater as a cultivation medium of microalgae Chlorella vulgaris. Energy Procedia, 47, 56-61. https://doi.org/10.1016/j.egypro.2014.01.196

Effendi, H., Seroja, R., \& Hariyadi, S. (2019) Response surface method application in tofu production liquid waste treatment. Indonesian Journal of Chemistry, 19(2), 298-304. https://doi.org/10.22146/ijc.31693

Faisal, M., Mulana, F., Alam, P. N., \& Daimon, H. (2014). Wastewater characteristics from tofu processing facilities in Banda Aceh. The Proceedings of The 4th Annual International Conference Syiah Kuala University (AIC Unsyiah). http://www.jurnal.unsyiah.ac.id/AICSSciEng/article/view/2437

Faisal, M., Gani, A., Mulana, F., \& Daimon, H. (2016). Treatment and utilization of industrial tofu waste in Indonesia. Asian Journal of Chemistry, 28(3), 501-507. https://doi.org/10.14233/ajchem.2016.19372

Febrianti, F., Syamsu, K., \& Rahayuningsih, M. (2017) Bioethanol production from tofu waste by simultaneous saccharification and fermentation (SSF) using microbial consortium. International Journal of Technology, 5, 898-908. https://doi.org/10.14716/ijtech.v8i5.872

Guba, E. G., \& Lincoln, Y. S. (1994). Competing paradigms in qualitatitve research. In N. K. Denzin, \& Y. S. Lincoln (Eds.), Handbook of Qualitative Research (pp. 105-117). Thousand Oaks: Sage.

Gorobets, A. (2014). Eco-centric policy for sustainable development. Journal of Cleaner Production, 64, 654-655. https://doi.org/10.1016/j.jclepro.2013.09.022 
Government of Salatiga. (2012). Buku Putih Sanitasi Kota Salatiga Provinsi Jawa Tengah. http://ppsp.nawasis.info/dokumen/perencanaan/sanitasi/pokja/bp/kota.salatiga/BAB\%203\%20status\%202\%20juli\%202012.pdf

Haidir, M., \& Sudrajat, A. (2014). Water Footrpint of Tofu and Tempeh Consumption in Bandung (Water Footprint Konsumsi Tahu dan Tempe di Kota Bandung). Jurnal Tehnik Lingkungan, 20(1), 20-28. https://doi.org/10.5614/jtl.2014.20.1.3

Hidayani, H., Sufardi, S., \& Hakim, L. (2015). Tofu Waste to Improve Chemical and Biological Properties of Soils and Sweet Corn (Zea mays var. Saccharata sturt L.) (Limbah Tahu untuk Memperbaiki Sifat Kimia dan Biologi Tanah serta Hasil Tanaman Jagung Manis (Zea mays var. Saccharata sturt L.)). Jurnal Manajemen Sumberdaya Lahan, 4(1), 572-578. https://onesearch.id/Record/IOS1725.article-7159

ILO (International Labour Organization). (2013). Clean Production to Improve Productivity (Produksi Bersih meningkatkan Produktivitas). Jakarta: ILO.

Kaswinarni, F. (2007). Technical Study on Tofu and Solid Waste Liquid Processing Industry: Case Study of Semarang Tandang Industry, Simplified Kendal and Crow Crow Boyolali (Kajian Teknis Pengolahan Limbah Padat dan Cair Industri Tahu: Studi Kasus Industri Tahu Tandang Semarang, Sederhana Kendal dan Gagak Sipat Boyolali). Semarang: Universitas Diponegoro.

Kementerian Lingkungan Hidup. (2014). Peraturan Menteri Lingkungan Hidup Republik Indonesia Nomor 5 Tahun 2014 tentang Baku Mutu Air Limbah. Jakarta. http://neo.kemenperin.go.id/files/hukum/17\%20Permen\%20LH\%20th\%202014\%20No.\% 2005\%20Baku\%20Mutu\%20Air\%20Limbah.pdf

Komalasari, W. B., Sabarella, Wahyuningsih, S., Manurung, M., Herwulan, M., Sehusman, Supriati, Y., \& Rinawati. (2017). Statistik Konsumsi Pangan Tahun 2017. Jakarta: Kementerian Pertanian. http://epublikasi.setjen.pertanian.go.id/arsip-perstatistikan/163statistik/statistik-konsumsi/531-statistik-konsumsi-pangan-tahun-2017

Kruis, F. (1995). Environmental Chemistry Selected Analytical Methods: Laboratory manual. Delft: IHE.

Oktariany, A., \& Kartohardjono, S. (2018). Effect of coagulant dosage on tofu industry wastewater treatment in combination with ultrafiltration process using polysulfone $\begin{array}{lllll}\text { membrane. } & \text { E3S } & \text { of } & \text { Conferences, } & 67,\end{array}$ https://doi.org/10.1051/e3sconf/20186704004

Ridha, M. (2015). Impact Sheet - SWITCH Asia project: Scaling Sustainable Consumption and Production - Promoting eco-friendly production in Indonesian tofu and tempeh industry. https://www.switch-asia.eu/fileadmin/user_upload/Switch_Asia_Impact_Sheet_-_2015__Soybean_Processing_SCOPE____screen.pdf

Ristianingsih, D., Dharmawan, A. H., \& Putri, E. I. K. (2018). Analysis of Sustainability of Rural Tofu Waste Biogas (Case Study in Kalisari Village, Banyumas Regency) (Analisis Keberlanjutan Biogas Limbah Tahu Pedesaan (Studi Kasus Di Desa Kalisari, Kabupaten Banyumas)). Jurnal Ilmu Lingkungan, 16(2), 104-112. https://doi.org/10.14710/jil.16.2.104-112

Saenab, S., Henie, M., Al, I., Rohman, F., \& Arifin, A. N. (2018). Utilization of Tofu Industry Liquid Waste as Liquid Organic Fertilizer (POC) to Support the Makassar City (Loose) Aisle Garden Program (Pemanfaatan Limbah Cair Industri Tahu Sebagai Pupuk Organik 
Cair (POC) Guna Mendukung Program Lorong Garden (Longgar) Kota Makassar). Prosiding Seminar Nasional Megabiodiversitas Indonesia. http://journal.uinalauddin.ac.id/index.php/psb/article/view/5935

Sahirman, S., \& Ardiansyah. (2014). Assessment of Tofu Carbon Footprint in Banyumas, Indonesia - Towards "Greener" Tofu. Proceeding of International Conference on Research, Implementation and Education of Mathematics and Sciences 2014. https://eprints.uny.ac.id/11443/

Seroja, R., Efendi, H., \& Hariyadi, S. (2018). Tofu wastewater treatment using vetiver grass (Vetiveria zizanioides) and zeliac. Applied Water Science 8(2). https://doi.org/10.1007/s13201-018-0640-y

Surono, I. S. (2016). Ethnic Fermented Foods and Beverages of Indonesia. In J. P. Tamang (Ed.), Ethnic Fermented Foods and Alcoholic Beverages of Asia (pp. 341-382). India: Springer.

Syaifudin, N., Nurkholis, Handika, R., \& Setyobudi, R. H. (2018) The importance of credit program scheme on waste to energy program in Indonesia: Case study on tofu industry. $\begin{array}{lllll}\text { MATEC Web } & \text { Conferences, } & 164,\end{array}$ https://doi.org/10.1051/matecconf/201816401032

Thompson, Z. C. S. \& Barton, M. A. (1994). Ecocentric and Anthropocentric Attitudes toward the Environment. Journal of Environmental Psychology, 14, 149-157. https://doi.org/10.1016/S0272-4944(05)80168-9

Widaningrum, I. (2015). Environmentally Friendly (Waste-Free) Tofu Making Technology (Teknologi Pembuat Tahu Yang Ramah Lingkungan (Bebas Limbah)). Jurnal Dedikasi, 12, 14-21. http://ejournal.umm.ac.id/index.php/dedikasi/article/view/2476 